NERC Open Research Archive

Centre for

Ecology \& Hydrology

NATUMAL ENVIMONHENT RESEARCH COUNCIL.

Article (refereed) - postprint

Harris, Michael P.; Wanless, Sarah; Ballesteros, Manuel; Moe, Borge; Daunt, Francis; Erikstad, Kjell Einar. 2015. Geolocators reveal an unsuspected moulting area for Isle of May common guillemots Uria aalge.

(C) 2015 British Trust for Ornithology

This version available http://nora.nerc.ac.uk/509728/

NERC has developed NORA to enable users to access research outputs wholly or partially funded by NERC. Copyright and other rights for material on this site are retained by the rights owners. Users should read the terms and conditions of use of this material at http://nora.nerc.ac.uk/policies.html\#access

This is an Accepted Manuscript of an article published by Taylor \& Francis Group in Bird Study on 09/02/2015, available online: http://www.tandfonline.com/10.1080/00063657.2015.1006164 


\title{
2 Geolocators reveal an unsuspected moulting area for Isle of May 3 Common Guillemots Uria aalge
}

\author{
MICHAEL P. HARRIS ${ }^{1 *}$, SARAH WANLESS ${ }^{1}$, MANUEL BALLESTEROS ${ }^{2}$, BØRGE MOE ${ }^{3}$, FRANCIS \\ DAUNT ${ }^{1}$ and KJELL EINAR ERIKSTAD ${ }^{2,4}$ \\ ${ }^{1}$ Centre for Ecology \& Hydrology, Bush Estate, Penicuik, Midlothian EH26 OQB UK; ${ }^{2}$ Norwegian \\ Institute for Nature Research, FRAM - High North Research Centre on Climate and the Environment, \\ 9296 Tromsø, Norway; ${ }^{3}$ Norwegian Institute for Nature Research, 7485 Trondheim, Norway; ${ }^{4}$ Centre \\ for Conservation Biology, Department of Biology, Norwegian University of Science and Technology, \\ NO-7049 Trondheim, Norway \\ ${ }^{*}$ Correspondence author. Email: mph@ceh.ac.uk
}

Capsule Data from geolocators deployed on adult Common Guillemots from a colony in southeast Scotland indicated that they normally winter in the North Sea up to $1000 \mathrm{~km}$ southeast of the colony. However, one bird unexpectedly moved $3000 \mathrm{~km}$ northeast to moult in the Barents Sea.

Ringing has shown that adult Common Guillemots Uria aalge from the Isle of May, southeast Scotland $\left(56^{\circ} 11^{\prime} \mathrm{N}, 2^{\circ} 33^{\prime} \mathrm{W}, \mathrm{c} .15,000\right.$ pairs in 2010$)$ disperse outside the breeding season with recoveries along coasts from Shetland and southwest Norway, south to the Bay of Biscay and west to southern Ireland but with concentrations along the southern and western shores of the North Sea (Fig. 1; Reynolds et al. 2011). Such recoveries give a general picture of distribution but probably under-represent birds wintering well offshore since birds dying there are unlikely to be reported and the distribution of those that are found will be highly biased towards locations with accessible coastlines that are regularly visited by members of the public. However, the development of miniature ring-mounted geolocators has revolutionized our ability to track seabirds that winter in remote regions and/or well away from land and has produced spectacular results that would have been impossible with traditional ringing (Egevang et al. 2010, Mosbech et al. 2012, Stenhouse et al. 2012). We therefore deployed geolocators on Guillemots breeding on the Isle of May to obtain wintering distributions to check if they highlighted the use of previously unsuspected areas. 
Adults with chicks on the Isle of May were caught using a noose attached to a 3-m pole or lowered over the head using a fishing rod in June $2011(n=40), 2012(n=25)$ and $2013(n=40)$. Birds were caught in five sub-colonies where catching caused minimal disturbance. Each bird was equipped with a geolocator (British Antarctic Survey, Cambridge, UK Mk15 in 2011 \& 2012; Biotrack, Dorset, UK, Mk3006 in 2013) attached to a plastic ring (combined weight $3.5 \mathrm{~g}$ or $<0.4 \%$ the mass of the adults on which they were deployed) placed on one leg and a B.T.O. ring on the other leg. The procedure took less than 3 min and most birds returned to the ledge immediately. To minimize disturbance we did not wait in the colony until we had seen all the birds come back or record whether individual birds fledged chicks. Seventy geolocators were retrieved in subsequent years, providing information on the winters of 2011-12 (25 birds), 2012-13 (14 birds) and 2013-14 (22 birds). Each year, some additional birds with loggers were present in the sub-colonies but were not caught since this is an ongoing study and we wished to leave some devices on for several winters.

Light data from the geolocators were processed using the BASTrak software package (Fox 2010). We inspected daily light curves and estimated the timing of dawn and dusk using a threshold of 10. Latitude, derived from day or night length, and longitude, derived from the timing of local midday or midnight, were calculated using a sun elevation angle of $-3^{\circ}$ and the compensate movement function (Fox 2010). Latitudes are unreliable around the equinoxes so positions 7 September to 19 October and 24 February to 5 April were excluded. Average error is in the order of $\pm 200 \mathrm{~km}$ for geolocators (Phillips et al. 2004) so for birds with coastal distributions many positions will be on land and such positions were not filtered out. However, a few clearly unrealistic positions $(<1 \%$ of all locations), such as short-term ( 1 or 2 day) 'spikes' deviating $>750 \mathrm{~km}$ from the core distribution of an individual's location or track, were removed. Winter was defined as 20 October to 23 February and kernel density maps for this period were produced in R 3.0.3 (R Development Core Team 2014). Utilization distributions were estimated using Kernel density distribution with the "kernelUD" function in the "adehabitat" package (Calenge 2006).

Between 1981 and 2013, 3,818 full grown and 13,430 young Guillemots were ringed on the Isle of May giving 149 recoveries of birds 4 or more years old during the winter (defined as OctoberMarch). This was a slightly longer period than used for the geolocators to allow for the likely delay between a ringed bird dying and being found and reported. These recoveries were plotted along with the 95,75 and $50 \%$ kernel density contours using the same methods as for the geolocators. The 
function "kerneloverlaphr" in the "adehabitat" package (Calenge 2006) was used to calculate the proportional overlap between the $50 \%$ Kernel density estimations for geolocator positions and ringing recoveries shown in Figure1.

The winter range of Isle of May Guillemots as shown by geolocators covered the entire North Sea, the Kattegat, the seas just north of Scotland and the very southern Norwegian Sea (Fig. 1a). However, the core area was the central, western and southern parts of the North Sea. The winter distribution as indicated by the ringing recoveries was similar, with a proportional overlap of $45 \%$ of the $50 \%$ kernels (the core area), although slightly more extensive, especially through the English Channel and into the Bay of Biscay (Fig. 1b). This might have been due to the much larger sample size for recoveries since one bird with a geolocator was found dead in Charente-Maritime, France $\left(45^{\circ} 41^{\prime} \mathrm{N}, 1^{\circ} 14^{\prime} \mathrm{W}\right)$ in February 2014 . Its geolocator had ceased functioning so the bird was treated as a ringing recovery and is the southernmost recovery plotted in Figure $1 \mathrm{~b}$. Thus, overall the geolocator results indicated that Guillemots from the Isle of May made considerable use of the open sea, at least in the southern North Sea where the waters are relatively shallow.

However, one bird did something unexpected (Fig. 2). This individual had been ringed as a chick on the Isle of May in 2001 and so was 12 years old when the geolocator was deployed on 26 June 2013 in the same sub-colony as it was ringed and had also been recorded breeding in 2008. Data from the geolocator indicated that during July 2013 the bird moved away from the Isle of May into the northern North Sea so that by 31 July it was off the coast of Norway at c. $65^{\circ} \mathrm{N}$. It continued to move north but since the light intensity at these latitudes is constantly higher than the dusk/dawn threshold of the geolocator at this time of the year, there were no further fixes until 20 August. By this date the bird had rounded the North Cape and was in the Barents Sea, presumably with the large numbers of Guillemots from colonies in North and Central Norway that occur here at this time (Barrett \& Golovkin 2000). It remained in the Barents Sea for two months before leaving on 25 October, was back at $65^{\circ} \mathrm{N}$ four days later and in the North Sea east of the Isle of May by 4 November. The bird spent the remainder of the winter in the northern North Sea and around southwest Norway (Fig. 2). There have been 754 recoveries of Guillemots ringed on the Isle of May but none of these has been north of the Arctic Circle which makes this bird quite exceptional. 
97 Guillemots were last seen at their sites between 5 and 10 July. Following breeding, Common

98 Guillemots and Brünnich's Guillemots Uria lomvia undergo a full moult during which they are flightless. Observations of captive Common Guillemots suggest that this lasts for 4-6 weeks (Birkhead \& Taylor 1977), whereas data-loggers deployed on Brünnich's Guillemots suggested a period of 9-11 weeks (Elliott \& Gaston 2014). The only place that the geolocator bird could have been incapable of flight for more than 4 weeks was when it was in the Barents Sea after its northeastward migration of c. $3000 \mathrm{~km}$. This behaviour contrasts with that of Brünnich's Guillemots that became flightless within days of leaving the colony (Elliott \& Gaston 2014). Guillemots breeding on the Isle of May visit their breeding sites during the late autumn (Harris \& Wanless 1989) and Guillemots were seen on the ledges on 8 November 2013 (Matt Bivins pers. comm.). This Barrent's Sea visitor returned to the general vicinity of the Isle of May at this time,so it could well have visited its breeding site. In contrast, fixes between December and February suggested that the bird was usually well away from the colony, behaviour that accords with normal year-round patterns of attendance on the Isle of May (Harris \& Wanless 1984).

While the areas used in autumn and winter by this Isle of May bird was exceptional for this population, they were remarkably similar to those of Guillemots breeding at Sklinna, Central Norway $\left(65^{\circ} 13^{\prime} \mathrm{N}, 10^{\circ} 58^{\prime} \mathrm{E}\right)$. Birds from this colony initially move north to the Barents Sea, move south in the late autumn or early winter to waters of southern Norway and occasionally enter the northern North Sea (Lorentsen \& May 2012, personal data). Although Guillemots are highly philopatric, ringing of chicks has shown that small numbers do recruit to colonies well away from where they were hatched. For instance, eight chicks ringed in northern Scotland and the Western Isles have been recorded when they were five or more years old in the breeding season at the Norwegian colonies of Sklinna, Hernyken, $\left(67^{\circ} 26^{\prime} \mathrm{N}, 11^{\circ} 52^{\prime} \mathrm{E}\right)$, and Hornøya $\left(70^{\circ} 23^{\prime} \mathrm{N}, 31^{\circ} 09^{\prime} \mathrm{E}\right)$ and were, or could potentially have been, breeding (S-H. Lorentsen pers. comm., T. Anker-Nilssen pers. comm., R.T Barrett pers. comm.). However, we know that the geolocator bird had been reared on the Isle of May so was definitely not an immigrant from Norway. Guillemots ringed in the far north of Scotland have been recovered in the autumn and winter along the coast of Norway up to the Barents Sea (Harris \& Swann 2002, Robinson \& Clark 2014) so deployment of geolocators on Guillemots in colonies in Shetland may well indicate that the Barents Sea is an important moulting are for these populations. 


\section{ACKNOWLEDGEMENTS}

The study was funded by Norwegian oil companies (Norsk Olje and Gas) and we acknowledge Egil Dragsund for his interest to follow up our needs. We thank Scottish Natural Heritage for permission to work on the Isle of May NNR and Kees Camphuysen and another reviewer for improving the manuscript with their comments.

\section{REFERENCES}

Barrett, R. T. \& Golovkin, A. N. 2000. Common Guillemot Uria aalge. In Anker-Nilssen, T., Bakken, V., Strøm, H., Golovkin, A. N., Bianki, V. V. \& Tatarinkova, I. P. e. (eds) The Status of the Marine Birds breeding in the Barents Sea Region: 114-118. Norsk Polarinst. Rapp. Ser. 113. Norwegian Polar Institute, Tromsø.

Birkhead, T. R. \& Taylor, A. M. 1977. Moult of the Guillemot Uria aalge. Ibis 119: 80-85.

Calenge, C. 2006. The package adehabitat for the R software: a tool for the analysis of space and habitat use by animals. Ecol. Model. 197: 516-519.

Egevang, C., Stenhouse, I. J., Phillips, R. A., Petersen, A., Fox, J. W. \& Silk, J. R. D. 2010. Tracking of Arctic terns Sterna paradisaea reveals longest animal migration. Proc. Natl. Acad. Sci. U.S.A. 107: 2078-2081.

Elliott, K.H. \& Gaston, A.J. 2014 Dive behaviour and daily energy expenditure in Thick-billed Murres Uria lomvia after leaving the breeding colony. Mar. Ornith. 42: 183-189.

Fox, J.W. 2010. Geolocator Manual v8 (March 2010), British Antarctic Survey, Cambridge.

Harris, M. P. \& Swann, R. L. 2002. Common Guillemot (Guillemot) Uria aalge. In. Wernham, C. V., Toms, M., Marchant, J. H., Clark, J. A., Siriwardena, G. M. \& Baillie, S. R. (eds.). The Migration Atlas; movements of the birds of Britain and Ireland, 397-400. T. \& A.D. Poyser, London.

Harris, M. P. \& Wanless, S. 1984. The effect of the wreck of seabirds in February 1983 on auk populations on the Isle of May (Fife). Bird Study 31: 103-110.

Harris, M. P. \& Wanless, S. 1989. Fall colony attendance and breeding success in the Common Murre. Condor 91: 139-146.

Lorentsen, S.-H. \& May, R. 2012. Inter-breeding movements of common guillemots (Uria aalge) suggest the Barents Sea is an important autumn staging and wintering area. Polar Biol. 35: 1713-1719.

Mosbech, A., Johansen, K. L., Bech, N. I., Lyngs, P., Harding, A. M. A., Egevang, C., Phillips, R. A. \& Fort, J. 2012. Inter-breeding movements of little auks Alle alle reveal a key postbreeding staging area in the Greenland Sea. Polar Biol. 35: 305-311.

Phillips, R. A., Silk, J. R. D., Croxall, J. P., Afanasyev, V. \& Briggs, D. R. 2004. Accuracy of geolocation estimates for flying seabirds. Mar. Ecol. Prog. Ser. 266: 265-272.

R Core Development Team. 2014. R: A language and environment for statistical computing. $R$ Foundation for Statistical Computing, Vienna, Austria. Available at: http://www.R-project.org/. 
Reynolds, T. J., Harris, M. P., King, R., Swann, R. L., Jardine, D. C., Frederiksen, M. \& Wanless, S. 2011. Among-colony synchrony in the survival of Common Guillemots Uria aalge reflects shared wintering areas. Ibis 153: 818-831.

Robinson, R.A. \& Clark, J.A. 2014. The Online Ringing Report: Bird ringing in Britain \& Ireland in 2013. BTO, Thetford (http://www.bto.org/ringing-report, created on 30-May-2014).

Stenhouse, I. J., Egevang, C. \& Phillips, R. A. 2012. Trans-equatorial migration, staging sites and wintering area of Sabine's Gulls Larus sabini in the Atlantic Ocean. Ibis 154: 42-51. 


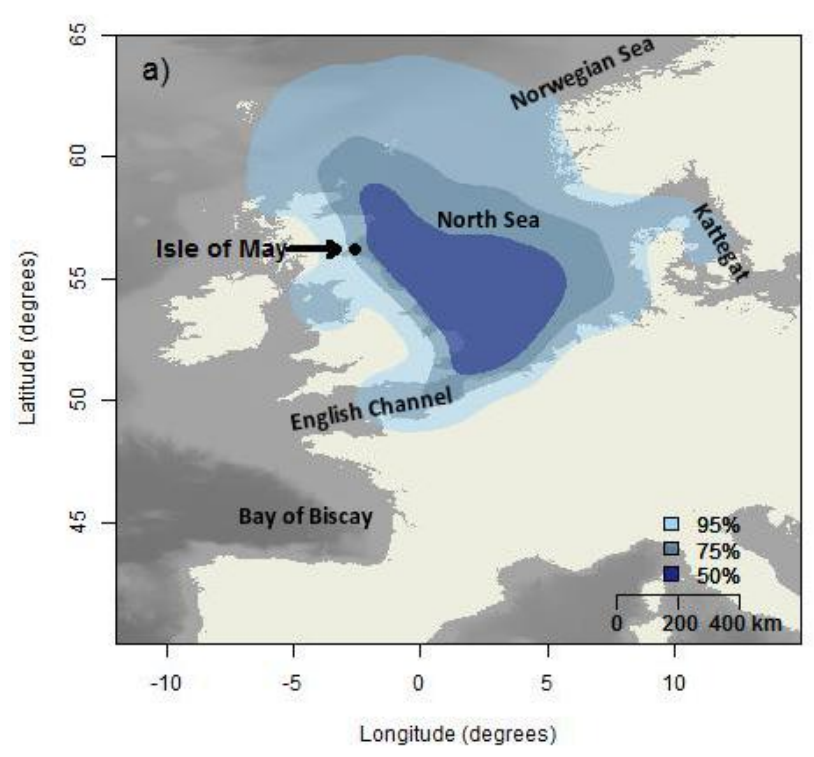

188

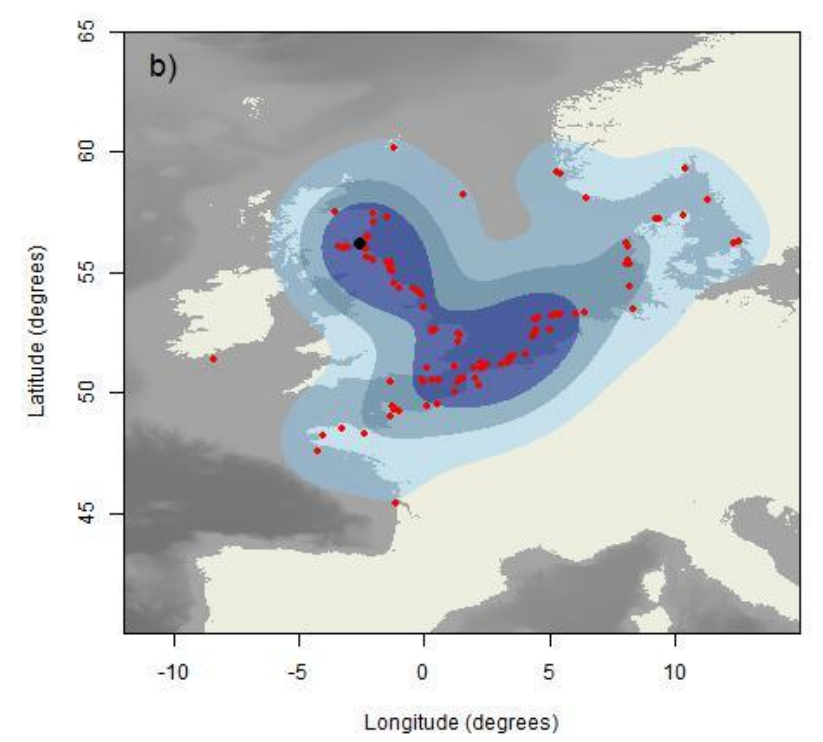

189

190 Figure 1. a) Usage kernels 20 October to 23 February resulting from the deployment of geolocators 191 on Common Guillemots breeding on the Isle of May over the 2011-12, 2012-13 and 2013-14 winters based on 61 bird-winters. b) Locations of 149 recoveries (red dots) of Common Guillemots ringed on the Isle of May and reported during October-March when they were at least four years old. In both plots the $95 \%, 75 \%$ and $50 \%$ kernels are shown in increasing dark shades of blue. 


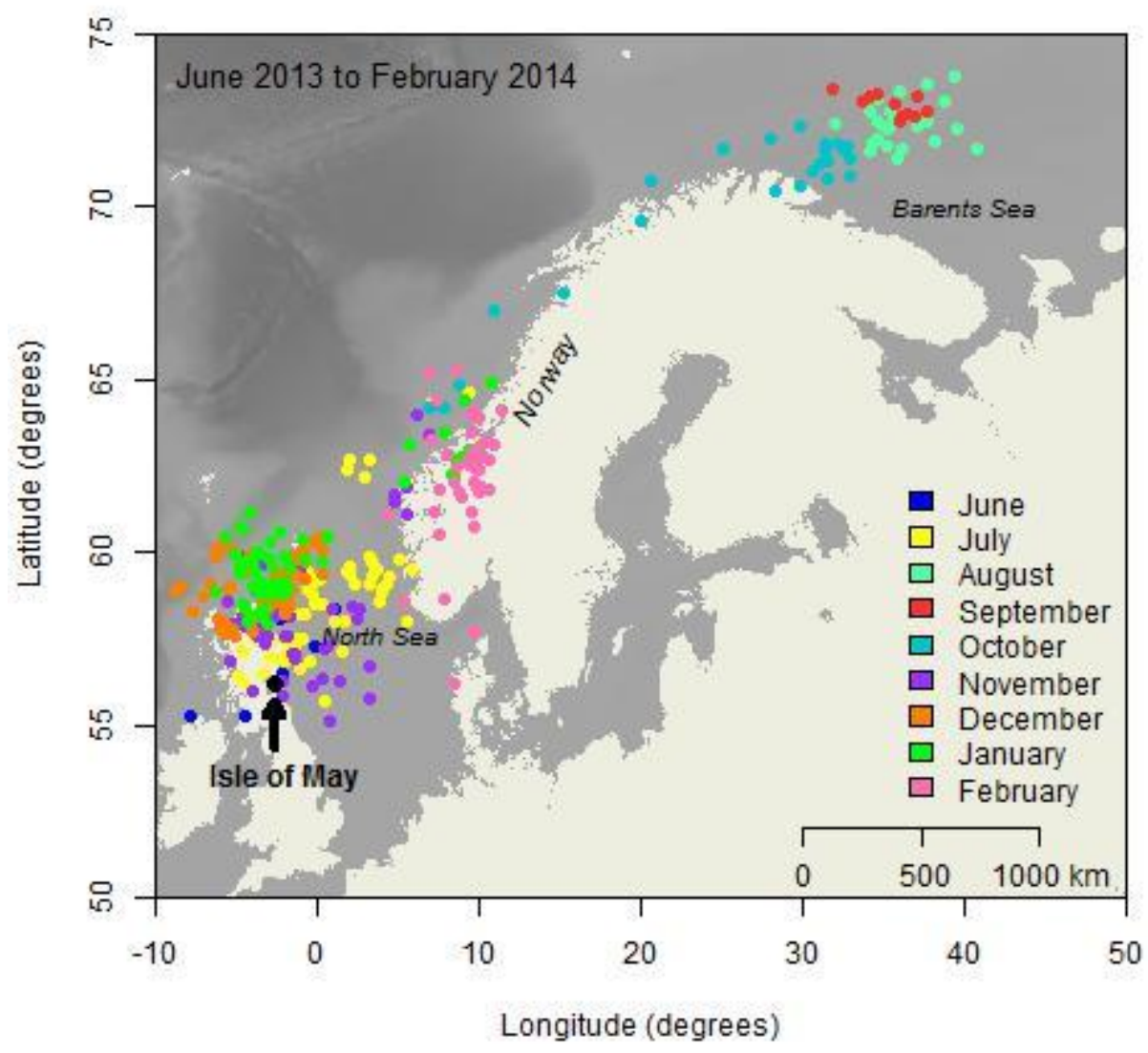

196

197 Figure 2. The movements of a Common Guillemot breeding on the Isle of May. The inaccuracy of

198 geolocators is in the order of $\pm 200 \mathrm{~km}$ (Phillips et al. 2004). Many estimated positions over land

199 indicate that the bird was relatively close to the shore in parts of the year, and they were not filtered

200 out (see methods).

201

202 